\title{
Resource-Based Approach in Creating Competitive Advantages for Public Schools of Economics
}

\author{
Ing. Josef Krause, Ph.D. \\ University of Economics, Prague, Faculty of Business Administration, \\ W. Churchill Sq. 4, 13067 Prague 3, Czech Republic \\ E-Mail: krausej@vse.cz
}

\section{Doi:10.5901/mjss.2015.v6n4p13}

\begin{abstract}
Public economics-oriented universities in the Czech Republic are currently facing a shortage of students and fierce competition. This paper deals with approaches to creating competitive advantages in this respect. The aim of the presented research is to verify the importance of each category of resources to build competitive advantage at public universities. Specifically, the paper discusses three basic approaches: external approach, resource-based approach, and innovation-based approach. The paper presents results of a survey that focused on evaluating the importance of individual resource groups. The realized research confirmed the generally accepted fact that human resources and other intangible resources are the most important resources for competitive advantage creation. In particular, the quality of teachers, their level of expertise as well as their access to students appears to be a crucial factor. Further, it contains a statistical evaluation of differences between views of students on the importance of individual resources in relation to their satisfaction.
\end{abstract}

Keywords: competitive advantage; resource-based approach; innovation; external approach; university

\section{Introduction}

Grant (2013) defines a competitive advantage as the company's ability to achieve a higher level of profitability in a particular market than its competitors. The basis for creating this very ability may lie either outside or inside the company. According to Porter (2004), a competitive advantage, in essence, comes from the value that the company is able to create for its customers. This value must exceed the costs of its creation. According to this author, companies use two types of competitive advantages - cost leadership and differentiation.

Based on the study of relevant professional literature (Grant, Porter, Barney, Drucker, Kim, and Mauborgne), it is possible to identify three approaches to gain a competitive advantage: external, resource-based, and innovation-based.

\subsection{Approaches to Creating a Competitive Advantage}

\subsubsection{External Approach}

Porter (2004a, 2004b, 2008) sees the main factor determining the profitability of a company in the level of competitive rivalry in the given field or industry. Every company should, first of all, try to understand the principles of functioning of its competitive environment, which determine its attractiveness, and subsequently - using its possibilities - use them in its favour. According to Porter, the main factors that affect the competitiveness in the industry are the following five: entry of new competitors, threat of substitute products or services, bargaining power of buyers, bargaining power of suppliers, and rivalry among existing competitors. The intensity of these factors determines to which extent the industry is profitable, as they influence the prices, costs, and investment in the given industry. Porter assumes that an industry's profitability does not depend on the quality of the product, the level of technology, or the like, but primarily on the structure of that industry. If companies could not change the structure of the industry, then the key element of a successful strategy would be the ability to recognize this structure better than the competition and to choose a highly profitable industry. Yet, companies are capable of changing the above five factors by means of their strategy. The importance of components of the structure of various industries differs. For a company which has changed the structure, it does not always mean a change for the better. A change leading to short-term profits may means a loss in the long run. To the achievement of a competitive advantage leads to competing strategies: cost leadership and differentiation. The strategy of a cost-oriented competitive advantage is based on providing a standard product for a lower price. The differentiation strategy, in turn, focuses on 
premium products for a higher price.

Also other authors see potential for gaining a competitive advantage outside the company. An external source of a competitive advantage may be, for example, changing consumer preferences, price changes, etc.

If a competitive advantage is to emerge, companies must be prepared to respond to this change. This is why a change in the environment has different impacts on different companies. The size of the impact of a change is dependent on the size of that change and the readiness and ability of companies to respond to it. Companies must be able to adequately use their resources to be able to use changes in their favour. (Grant, 2013, 2012)

\subsubsection{Resource-Based Approach}

Another approach to building up a competitive advantage is to look for it inside the organization. This approach explains the fact why different companies in the same industry achieve various profitability.

The term "resources" encompasses "assets, capabilities, organizational processes, company attributes, information, knowledge, etc.". All resources must have several characteristics if their to became a basis for a competitive advantage. These basic characteristics are value, rarity, imperfect imitability, and difficult substitutability (Barney, 1991; Barney, 2001a, 2001b, Barney et al., 2011). We can also find a more detailed version of these characteristics distinctive, bargain, inseparable, matchless (Mathur, Kenyon, 2001, 1997).

Individual characteristics are very important. Resources must be valuable to have the potential for the use of the opportunities and to avoid risks resulting from the environment. The rarity of resources is important so that the resources are not available to competitors. At the same time, these valuable and rare resources must be inimitable by other sources. This inimitability may be caused by history dependency, causal ambiguity, and social complexity. The last requirement is non-substitutability of these valuable resources. The combination of these characteristics of resources may create a sustainable competitive advantage (Barney, 1991).

We can distinguish four basic group of resources: tangible, human, financial, and intangible (Sedláčkova, Buchta, 2006). Other authors use "financial resources, assets, business plan" (Timmons and Spinelli (2003) or a more detailed breakdown, such as "physical, reputational, organizational, financial, intellectual, technological." (Dollinger, 2003). Evaluation of characteristics of individual kinds of resources in terms of their potential for creating a competitive advantage is shown in Table 1.

Table 1. Characteristics of Individual Resources

\begin{tabular}{|l|c|c|c|c|}
\hline Resource & Valuable & Rare & Inimitable & Non-substitutable \\
\hline Tangible & Yes & Sometimes & Mostly no & Sometimes \\
\hline Company reputation & Yes & Yes & Yes & Yes \\
\hline Organizational & Yes & Yes & Yes & Yes \\
\hline Financial & Yes & Sometimes & No & No \\
\hline Human and intellectual resources & Yes & Yes & Mostly yes & Sometimes \\
\hline Technological & Yes & Sometimes & Sometimes & Sometimes \\
\hline
\end{tabular}

Source: Dollinger (2003)

The evaluation suggests that the potential for creating competitive advantages may have all sources. However, it is usually intangible and human resources that are rare and hard to imitate or substitute.

\subsubsection{Innovation-Based Approach}

Another source of competitive advantages are innovations. Innovation activities allow companies to create value for customers. Strategic innovation can create new industries, new customer segments, and new sources of competitive advantages. Innovation not only creates a competitive advantage, but allows you to take away competitive advantages of other companies. Innovative strategies include new approaches to competition within the industry. Innovative strategies are usually the foundation of the greatest achievements in most industries. In fact, they stand behind success far more often than innovations of products or services (Grant, 2013).

A very famous one is the "blue ocean strategy". This strategy is based on value innovation and creation of new industries (Kim, Maubrogne, 2004, 2005a, 2005b). According to the strategy, long-term conflict with other competitors 
leads to depletion of organizations and the threat of extinction.

We can also come across the term "investigative strategy". This strategy should enable achievement of the company's goals without being directly in conflict with competing businesses. Here, the requirements are customer knowledge and strategic partnerships with competitors (Bartes, 2006, 2010). Direct offensive / combat strategy appears to be unsustainable (Bartes, 2011).

\subsection{Development of the Number of University Students and Applicants}

In recent years, Universities in the Czech Republic have faced with a declining number of applicants and students. Graph 1 shows trends in the number of students of private and public universities.

Graph 1. The Number of Students of Private and Public Universities in the CR.

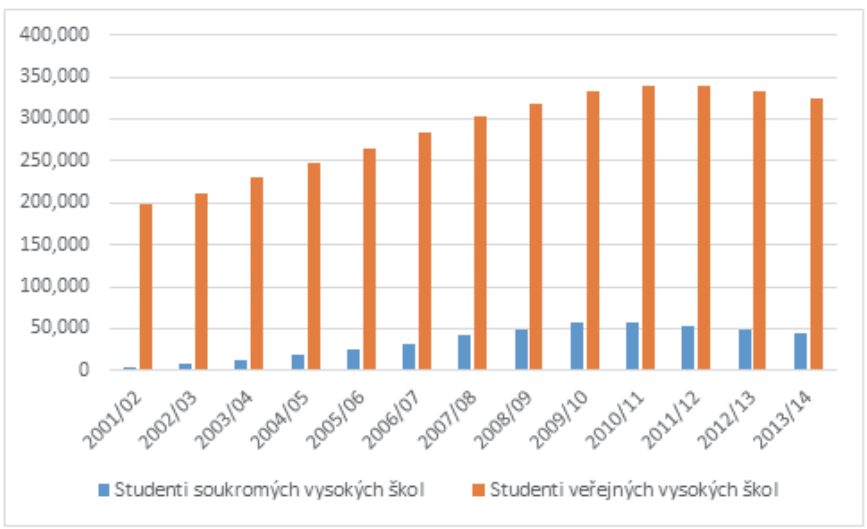

Source: Czech Statistical Office, 2014a

The number of students at public and private universities rose until 2010. After this year, there was a slight decrease in the number of students at both types of universities. The percentage of students in private universities in the last give years ranges between $12 \%$ and $15 \%$.

More than $50 \%$ of students attend economics-based universities (Czech Statistical Office, 2011).

In terms of future demand for these graduates, the expected demographic development is not very favourable. Table 2 shows the trend in the age groups $10-14$ years and $15-19$ years. These age groups are essential for universities as most of the future students recruit from these two.

Table 2. Number of Children Aged 15 - 19 in the Czech Republic

\begin{tabular}{|c|c|c|c|c|c|c|c|c|}
\hline Age & 2005 & 2006 & 2007 & 2008 & 2009 & 2010 & 2011 & 2012 \\
\hline Total & $10,234,092$ & $10,266,646$ & $10,322,689$ & $10,429,692$ & $10,491,492$ & $10,517,247$ & $10,496,672$ & $10,509,286$ \\
\hline $15-19$ & 655,132 & 652,191 & 648,090 & 642,190 & 626,876 & 599,205 & 560,122 & 525,652 \\
\hline
\end{tabular}

Source: Czech Statistical Office, 2013a

The development of these age categories is a threat for Czech universities. The number of children, especially in the age group $15-19$, has been steadily declining. For that demographic trend, it can be inferred a lack of potential applicants. It can be clearly assumed that there has been intensifying competition among universities.

Table 3 shows the number of applicants for private and public universities in the field of business economics. 
Table 3. Number of Applicants for Private and Public Universities in the Field of Business and Administration

\begin{tabular}{|l|c|c|c|c|}
\hline Fields of Study & 2009 & 2010 & 2011 & 2012 \\
\hline Total & 324,993 & 331,536 & 330,066 & 309,452 \\
\hline Science & 21,688 & 23,372 & 22,877 & 21,918 \\
\hline Engineering, manufacturing, and construction & 47,089 & 48,717 & 48,369 & 46,979 \\
\hline Agriculture, forestry, and veterinary & 10,078 & 10,938 & 10,850 & 11,598 \\
\hline Health & 28,389 & 31,250 & 32,520 & 34,042 \\
\hline Humanities and social studies & 72,967 & 71,223 & 67,194 & 61,775 \\
\hline Business and administration & 72,968 & $\mathbf{7 1 , 5 7 0}$ & $\mathbf{7 0 , 4 6 0}$ & $\mathbf{6 3 , 1 6 0}$ \\
\hline Law & 19,139 & 17,701 & 16,576 & 13,360 \\
\hline Education and social services & 42,227 & 46,358 & 50,797 & 46,773 \\
\hline Arts & 10,448 & 10,407 & 10,423 & 9,847 \\
\hline
\end{tabular}

Czech Statistical Office, 2009, 2011b, 2013b

In recent years, it is possible to trace a declining interest of applicants to study at universities. In economic fields, this trend is particularly evident between 2011 and 2012, when the decline was about $10 \%$. After law, economic fields of study are those where the drop has been the largest.

From the above statistics follows that Czech universities are currently struggling with declining numbers of students and applicants. This problem will intensify in the future due to developments in the demographic structure in the Czech Republic. Largely, the problems with the number of applicants are experienced by economics-oriented fields of study. Here, the problem is highlighted by the fact that most private universities provide education in this very field. Thus is resulting in the increasing need of these universities to become competitive.

The aim of this paper is to employ the resource-based approach at public universities in the Czech Republic and to evaluate the importance of individual components to create a competitive advantage.

\section{Methodology}

There was a survey carried out participated by 180 students of Business and Administration at Czech universities.

The survey was focused on the various types of the above-mentioned resources. The survey studied opinion of the students on these types, how they influence teaching, and their satisfaction with their level during the study.

To evaluate selected dependencies, the $x$-test of goodness of fit was used.

For testing was formulated a null hypothesis $(\mathrm{H} 0)$ and an alternative hypothesis $(\mathrm{H} 1)$. The null hypothesis states that the variables are independent. On the other hand, the alternative hypothesis states that the variables are dependent. The testing used the following criterion (Jarošová, 1994):

$$
\chi^{2}=\sum_{i} \quad \sum_{j} \frac{\left(n_{i j}-n_{i j}\right)^{2}}{n_{i j}}
$$

where $\mathrm{n}_{\mathrm{ij}}$ are observed frequencies,

$\mathrm{n}_{\mathrm{ij}} \mathrm{are}$ theoretical frequencies,

$i=1, \ldots r$, where $r$ is the number of table rows,

$\mathrm{j}=1, \ldots \mathrm{s}$, where $\mathrm{s}$ is the number of table columns.

Theoretical frequencies are calculated according to the formula:

$$
n_{i j}^{\prime}=\frac{n_{n} * n_{j}}{\mathrm{n}} \text {. }
$$

Theoretical frequencies should be higher in each category than 5 . For testing was determined the number of degrees of freedom, which is calculated as: $(r-1)^{\star}(s-1)$. To confirm the hypothesis, a standard $5 \%$ significance level is required.

Resources were divided into 4 groups based on basic premises of resource-based approach: tangible, intangible, human and organizational. Tangible resources included classroom teaching equipment and availability of teaching aids (especially literature). The group of intangible factors included an opportunity to participate in foreign study stays and an university offer of practice in companies. The human resources included the professional level of teachers and approach of teachers to students. The group organizational factors consisted of the capacity of announced courses and the capacity exam terms. 


\section{Results}

The basic question was the satisfaction of students with their selection of university. The vast majority of students were satisfied with their selection (65.56 \% of respondents). Another $27.22 \%$ of respondents answered rather satisfied. Only about $6 \%$ of respondents said they were rather dissatisfied with their choice. Only about $1 \%$ respondents were dissatisfied with the university they had selected. The next question served to verify the previous question (satisfaction with the selection of university). The question studied whether students would enrol again on the same university they studied. $85 \%$ of respondents answered positively and the remaining $15 \%$ of respondents would not enrol on the same university again.

Approximately $79 \%$ of respondents participated in a study stay abroad sometime during their study. $7 \%$ of respondents participated in a working stay during their study which their university had helped to arrange.

\subsection{Tangible Resources}

According to $92 \%$ of respondents, the level of equipment of classrooms is either good or rather good. According to $6 \%$ of respondents, the level of equipment of classrooms is rather poor. Only $2 \%$ of respondents said the level of equipment of classrooms is poor. $87 \%$ of respondents said that good classroom equipment is important for the quality of teaching. For $12 \%$ of respondents, this factor is rather unimportant for the quality of teaching. For $1 \%$ of respondents, this factor is not important at all.

Another area of interest in the field of tangible resources was the availability of teaching aids. According to $77 \%$ of respondents, the availability of teaching aids was good or rather good. According to $21 \%$ of respondents, the availability of teaching aids was rather poor and by about $3 \%$ of respondents, the availability of teaching aids was poor. When determining whether the availability of teaching aids was important for the quality of teaching, $95 \%$ of respondents felt that this factor was very important or rather important. For the remaining $5 \%$ of respondents, this factor was not important.

\subsection{Intangible Resources}

Other areas of research were the opportunities to and the importance of study stays abroad. According to $70 \%$ of respondents, the opportunities to carry out a study stay abroad were sufficient. The remaining $30 \%$ of respondents found these opportunities insufficient. Around $31 \%$ of respondents said the possibility to participate in a study stay abroad was important for the quality of education. $43 \%$ of respondents considered this factor rather significant, $23 \%$ rather insignificant, and $3 \%$ insignificant.

The university offer of working stays in companies was rated good by $6 \%$ of respondents and rather good for another $26 \%$ of respondents. $44 \%$ of respondents rated the offer of working stays in companies arranged by their university rather poor and $24 \%$ of respondents poor. This factor was very important for the quality of teaching for $56 \%$ of respondents and rather important for another $33 \%$ of respondents.

\subsection{Human Resources}

$38 \%$ of respondents rated the professional level of teachers good. Another $58 \%$ of respondents rated the level of teachers rather good. Only about $3 \%$ of respondents rated the level of teacher rather poor and $1 \%$ of respondents poor. The professional quality of teachers appears to be a crucial factor. $92 \%$ of respondents said this factor was very important for the quality of education and about $8 \%$ of respondents it was rather important. No respondents identified this factor as unimportant.

Another area of research was the approach of teachers to students. According to $26 \%$ of respondents, the approach of teacher to students was good. According to $69 \%$ of respondents, the approach of teacher to students was rather good. Only about $5 \%$ of respondents viewed the approach of teacher to students as poor or rather poor. Another question examined the importance of the student's approach for the quality of education. This factor was assessed as very important by $77 \%$ of respondents and by $23 \%$ as rather important. No respondents identified this factor as unimportant. 


\subsection{Organizational Resources}

Other factors examined belonged to the category of organizational factors. The research first addressed the capacity of announced courses. The capacity of announced courses was sufficient for $80 \%$ of respondents and insufficient for the remaining $20 \%$ of respondents. The capacity of announced courses was important for the overall quality of education for $29 \%$ of respondents and rather important for $47 \%$ of respondents. The remaining $24 \%$ of respondents assessed the capacity of courses unimportant or rather unimportant for the quality of education.

$36 \%$ of respondents were satisfied and $51 \%$ of respondents were rather satisfied with the capacity of exam dates. Rather dissatisfied were $12 \%$ of respondents and dissatisfied $2 \%$ of respondents. According to $20 \%$ of respondents, a sufficient capacity of exam terms is important for the overall level of education. Another $39 \%$ rated it as rather important. For $34 \%$ of respondents, this factor is rather unimportant for the quality of education and for $7 \%$ of respondents, this factor is unimportant.

For further evaluation, respondents were divided into two groups. The first group included students who would enrol on the same university again. The second group included students who would not enrol on the same university again.

To evaluate the importance of individual factors and the potential impact on the student's interest, the research statistically evaluated differences between different groups in the perception of individual resources.

First, it had to be verified whether both groups of respondents differ in their opinion on the importance of individual factors for the quality of education. The test used should confirm that respondents in both groups have the same opinion on the importance of individual factors. The next step was to evaluate differences between the groups in terms of their views on the satisfaction of factors. Any differences in individual groups may indicate that the factor is important in creating a competitive advantage based on the resource-based approach.

Table 4. Test criterion values and $P$-value

\begin{tabular}{|l|c|c|}
\hline Factor & Test criterion value & P-value \\
\hline Classroom equipment - importance & 0.739 & $0.39^{\star}$ \\
\hline Classroom equipment - satisfaction & 5.109 & $0.0238^{\star}$ \\
\hline Teaching aids - importance & 0.112 & $0.7375^{\star}$ \\
\hline Teaching aids - satisfaction & 5.381 & 0.204 \\
\hline Professional level of teachers - importance & - & - \\
\hline Professional level of teachers - satisfaction & 18.189 & $0.0000^{\star}$ \\
\hline Approach of teachers - importance & - & - \\
\hline Approach of teachers - satisfaction & 0.208 & 0.6486 \\
\hline Possibility of study stays abroad - importance & 0.249 & 0.6178 \\
\hline Possibility of study stays abroad - satisfaction & 0.002 & 0.9637 \\
\hline Offer of working stays in companies - importance & 1.399 & $0.2369^{\star}$ \\
\hline Offer of working stays in companies - satisfaction & 1.309 & 0.2525 \\
\hline Courses capacity - importance & 0.576 & 0.4480 \\
\hline Courses capacity - satisfaction & 3.529 & 0.0603 \\
\hline Capacity of exam terms - importance & 0.002 & 0.9662 \\
\hline Capacity of exam terms - satisfaction & 1.844 & $0.1744^{\star}$ \\
\hline
\end{tabular}

Note: - * Condition of the minimum relative frequency was not met.

Source: author

Opinions of students in both groups on the importance of individual factors for the quality of education do not differ. Also, there was not a difference in neither one factor in the perception of satisfaction with the various resources (however, except for satisfaction with classrooms equipment and professional level of teacher, satisfaction with facilities and professional level of teachers, the condition of the minimum relative frequency was not met.).

Based on the survey results, to evaluate the importance of individual factors for the quality of education, it was possible to create the following order of factors:

1. Professional level of teachers

2. Approach of teachers to students

3. Offer of working stays in companies 
4. Classroom equipment

5. Teaching aids

6. Possibility of study stay abroad

7. Capacity of announced courses

8. Capacity of exam terms

The most important, according to the research carried out, seems to be the factors of the group of human resources and intangible resources. Moderately important were the factors in the category of material resources. According to the respondents, the least important were the factors of organizational resources.

\section{Conclusion}

In the literature, we can meet three basic approaches for creating a competitive advantage: external, resource-based, and innovation-based. These concepts were gradually developed and found their application chiefly in the business sector. In the area of public universities, these approaches were generally avoided. Economics-oriented universities in the Czech Republic are now facing a decline in the number of applicants due to unfavourable developments in the demographic structure. They also face increased competition, because in the last 20 years a large number of private universities emerged. Therefore public universities have found themselves in a competitive environment that will continue to intensify. The resource-based approach is a concept that can be fully influenced by the given institution. It allows you to build up a successful organization even under ever-changing conditions of the external environment. The research confirmed the generally accepted fact that human and intangible resources are the most important. In particular, the quality of teachers, their professional level, and their approach to students appear to be crucial factors. If public universities are to continue to succeed in the competition, they must pay adequate attention to the development of these factors.

\section{Acknowledgements}

Supported by financial aid from the Internal Grant Agency at the University of Economics, Prague (project F3/49/2015).

\section{References}

Barney, J., Ketchen, D., J., Wright, M., "The Future of Resource-Based Theory: Revitalization or Decline?" 2011, Journal of Management, 5, p. 1299-1315.

Barney, J., "Resource-based theories of competitive advantage: A ten-year retrospective on the resource-based view", 2001a, Journal of Management, 6, p. 643-650.

Barney, J., "The resource-based view of the firm: Ten years after 1991", 2001b, Journal of management, 6, p. 625-641.

Barney, J., "Firm resources and sustained competitive advantage", 1991, Journal of management, 1, p. 99-120.

Bartes, F., "Modern competitive strategy firm", 2010, Acta Universitatis Agriculturae et Silviculturae Mendelianae Brunensis, 6, p. 51-58.

Bartes, F., "Comparing the potential use of oriental war philosophy and western combat strategies in the competition of companies", 2011, Acta Universitatis Agriculturae et Silviculturae Mendelianae Brunensis, 2, p. 21-24.

Bartes, F., "Nové směry v konkurenční strategii firmy", In: Kislingerova, E., Kopalova, H., Krause, J. (ed) . Nová teorie ekonomiky a managementu organizací Praha : Oeconomica, 2006, p. 71-78.

Czech Statistical Office, 2009, [Online] at http://notes.czso.cz/csu/2009edicniplan.nsf/kapitola/0001-09-2009-2100, accessed July $6^{\text {th }}$, 2014.

Czech Statistical Office, 2011 a, [Online] at (http://www.czso.cz/csu/2011edicniplan.nsf/t/6A0040887A/\$File/w-3316-11a1.pdf), accessed June 1 st, 2014.

Czech Statistical Office, 2011b, [Online] at http://notes.czso.cz/csu/2011edicniplan.nsf/kapitola/0001-11-2010-2300, accessed July $4^{\text {th }}$, 2014.

Czech Statistical Office, 2013 a, [Online] at http://www.czso.cz/csu/2013edicniplan.nsf/t/8E001797D4/\$File/4032130109.pdf, accessed July $4^{\text {th }}, 2014$.

Czech Statistical Office, 2013 b, [Online] at http://notes.czso.cz/csu/2013edicniplan.nsf/kapitola/0001-13-r_2013-2300, accessed July 4th, 2014.

Czech Statistical Office, 2014 a, [Online] at http:/www.czso.cz/csu/2014edicniplan.nsf/t/D9003FD97C/\$File/3201814_1208.pdf, accessed June 1st, 2014.

Dollinger, M., Entrepreneurship: strategies and resources, Upper Saddle River: Prentice-Hall, 2003.

Grant, R., Contemporary strategy analysis: text and cases. Chichester: Wiley, 2013.

Grant, R., Foundations of Strategy. Chichester:Wiley, 2012.

Jarošová, E., Statistika B: řešené přiklady, Praha: Vysoká škola ekonomická, 1994. 
Kim, W. Ch., Mauborgne, R. Blue ocean strategy: how to create uncontested market space and make the competition irrelevant. Boston: Harvard Business School Press, 2005a.

Kim, W.C., Mauborgne, R., 2005b, "Blue ocean strategy: From theory to practice", 2005b, California Management Review, 3, p. $105-121$. Kim, W.C., M.uborgne, R. 2004, "Blue ocean strategy", Harvard Business Review, 10, p. 76-84.

Mathur, S., S. a Kenyon, A,, Creating value: successful business strategies, Oxford: Butterworth-Heinemann, 2001.

Mathur, S. S. a Kenyon, A, Creating value: shaping tomorrow's business. Oxford: Butterworth-Heinemann, 1997.

Porter, Michael E, Competitive advantage: creating and sustaining superior performance. New York: Free Press, 2004a.

Porter, Michael E, Competitive strategy: techniques for analysing industries and competitors, New York: Free Press, 2004b.

Porter, Michael E, On competition. Boston: Harvard Business School Publishing, 2008.

Sedláčková, H., Buchta, K. Strategická analýza. Praha: C.H. Beck, 2006.

Timmons, J. A., Spinelli, S., New venture creation: entrepreneurship for the 21st century, Boston: McGraw-Hill, 2003. 